\title{
LAND AS A FUNDAMENTAL RigHT: A CAUTIONARY TALE
}

\author{
Sue Farran*
}

The article discusses the importance of land rights in the South Pacific for securing the enjoyment of other civil, political, economic, and social rights in the Pacific focusing especially on Vanuatu as a paradigm. The infringement of land rights and the abuse of natural resources in the Pacific have a long history and the consequences on human rights on the whole are severe. The article argues that current constitutional provisions do not go far enough to ensure that land rights are protected and consequently to ensure the enjoyment human rights as a whole.

\section{INTRODUCTION}

The purpose of this paper is to highlight the fundamental importance of land rights for securing the enjoyment of a wide range of other civil, political, economic and social rights in the Pacific region. It is argued that current constitutional provisions do not go far enough to ensure that the land rights of indigenous people are protected; that Governments have an obligation to take more effective measures in promoting the sustainable use of land and its related resources; and that external agencies need to reconsider the agendas they are setting for Pacific island countries if they hope to both foster and derive benefits from peace and stability in the region. In particular this paper focusses on land issues in Vanuatu, but much of what is stated applies equally to other Pacific islands which are characterised by rapidly growing populations, ${ }^{1}$ limited opportunity for outward

* Senior Lecturer, University of Dundee, Visiting Lecturer University of the South Pacific, and author of South Pacific Human Rights: Challenges and Changes (Routledge-Cavendish, London, 2009) (book review of this book in this volume).

1 Notably in Melanesian countries, especially Solomon Islands and Papua New Guinea but also in countries such as Kiribati, compare Tonga, Niue and Cook Islands where populations are stable or falling. 
migration; ${ }^{2}$ unsustainable economic development based on the exploitation of natural resources; ${ }^{3}$ and the possibility of aggravating land issues where such unsustainable development continues. ${ }^{4}$

\section{WHY LAND?}

Land and natural resources are central to a long history of rights abuse which continues to have consequences in the region and cannot be ignored. In Pacific islands this has included: the deforestation of many islands by sandalwood traders; the taking and redistribution of land seen as lying idle or neglected by colonial Governments; ${ }^{5}$ the use of Pacific islands for weapon testing; ${ }^{6}$ the taking of land for foreign military bases; ${ }^{7}$ and the exploitation of mineral resources by foreign companies at huge environmental cost. ${ }^{8}$ Even today foreign Governments appear to take advantage of the weak bargaining strength of Pacific islands and the geographical remoteness of their islands. ${ }^{9}$

Moreover, land is fundamental to identity, existence and survival in Pacific countries. ${ }^{10}$ For Pacific island people, as for many indigenous peoples elsewhere, ${ }^{11}$ land is more than its physical

2 Countries such as Papua New Guinea, Solomon Islands and Kiribati, compared with, for example, Cook Islands and Niue.

3 For example, hard wood logging in Solomon Islands and Papua New Guinea and fishing in much of the region.

4 For example, mining in Papua New Guinea.

5 For example, in Papua New Guinea, by 1906 the Crown held around 1,000,000 acres of land either through purchase from customary owners or by being declared waste and vacant (R Crocombe and R Hide "New Guinea" in Crocombe (ed) Land Tenure in the Pacific (University of the South Pacific, Suva, 1987) 342. Similar policies were adopted in Solomon Islands (H Scheffler and P Larmour "Solomon Islands: Evolving a new custom" in Crocombe (ed) 303,312) although it was later found that about 40,000 acres of land declared waste and vacant were found to be occupied under native custom and returned to the customary owners (F Kabui "Crown ownership of foreshores and seabed in Solomon Islands" (1997) J Pac S 123, 124). In Marshall Islands although the German administration did not pursue this policy, the Japanese did (W McGrath and W Scott Wilson "The Marshall, Caroline and Mariana Islands: Too many foreign precedents" in Crocombe (ed) 325-345.

6 Notably Bikini Atoll in Marshall Islands on 1 March 1954. The repercussions of this are still being adversely experienced by Marshallese as noted by leaders at the Pacific Forum at their 2006 meeting http://www.forumsec.org/pages.cfm/press-statments-2006/thirty-sventh-pacfiic-islands-forum.html (accessed 20 March 2007).

7 In Marshall Islands and Palau.

8 As in the case of phosphate in Nauru.

9 For example the setting up of Australian refugee asylum camps on Nauru and the trans-shipment of dangerous waste through Pacific islands' waters.

10 H Van Trease The Politics of Land in Vanuatu (Institute of Pacific Studies, University of the South Pacific, Suva, 1987) 3.

11 For example, aboriginal people in Australia and Māori in New Zealand. 
substance or exploitable potential. People and land are linked physically and spiritually. Where a person is from may be far more important than where they live; where they are buried may be far more significant than where they are born; where they are brought up may be far more significant than ties of affection.

Land issues illustrate the challenges which confront plural legal systems, such as those found in the Pacific region, where customary forms of land tenure remain central to the governance and use of land in many countries, especially those of Melanesia. It is not, however, customary land law that regulates contemporary development but rather introduced laws, which facilitate leases, mortgages, registered land dealings, strata-titles and time-shares. This raft of legislation can be used to develop land for social and economic purposes, for example, by enabling Governments to acquire land for public utilities, to provide greater security of tenure to those who are squatting on undeveloped urban land sites, or by enabling customary owners to raise mortgage finance for commercial enterprises or to improve the land which they retain, for example by providing better housing for their families. It can also be used in ways which confer little or no benefit on customary land owners or the public at large, for example by rendering large tracts of land inaccessible to indigenous people, by encouraging rapid and largely unregulated building construction, and by providing developers with opportunities to capitalise on the complexity of the legal framework and the ignorance of customary land owners. In other words, plural legal systems can operate in such a way so as to defeat or frustrate fundamental rights. ${ }^{12}$

Rights to land also provide examples of the dilemmas of group rights versus individual rights and the issue of rights versus duties. The fundamental right to property enshrined in the written constitutions of the region is framed as an individual right; although no individual right can be exercised or enjoyed without taking into account the corresponding rights of other individuals. Land held under various forms of customary land tenure is generally vested in more than one individual the family, lineage or clan. Although individuals may emerge as the prime decisions makers or managers of the land they are essentially present custodians for future generations. Often membership of different groups is fluid. For example, land may be exchanged as compensation or bride-price, or it may be forfeited or taken by force. One form of customary land tenure may be replaced by another in times of crisis, under the influence of missionary contact, or through intermarriage with groups practicing different customs, and then revert, perhaps several generations later, to a different previous form. Claims to titles which confer rights to land may be disputed, as may genealogies, which in turn may be complicated by various forms of adoption of children and adults. This fluidity sits uneasily with the notion of individual title to land, especially if that title

12 See generally Sue Farran "Is Legal Pluralism an obstacle to human rights? Considerations from the South Pacific" (2006) 52 JLP 77. 
becomes unchallengeable by means of registration, and if the title holder is then able to freely deal with the land as he (rarely she) wishes. ${ }^{13}$

At the same time, however, if the constitution confers an individual right to protection of property, why should an individual who has expended labour on property not be able to derive the benefit of this? If the only way to raise finance against the security of property is to create a lease over it then should the senior or more powerful members of a family be prevented from doing so, even if the money raised is squandered or the property seized by the lender in the case of mortgage default? In some systems individuals may be prevented from managing their own land, for example in Fiji the management of native land is the preserve of the Native Lands Trust Board. However, this does not prevent Fijian landowners entering into agreements which by-pass the Board, ${ }^{14}$ or from complaints being raised from time to time about the percentage of revenues to which Fijians, especially those who are commoners, are entitled. ${ }^{15}$

In rapidly changing economies individuals may be able to do things with land which communities or groups cannot, or they may wish to derive greater benefit from their land than they are entitled to under present arrangements. The Western neo-liberalism which informed the framing of bills of rights, also informed ideas and laws relating to property which were brought into the region and which continue to be the referral point for many land reformers and for individuals or groups seeking to exercise greater autonomy over their land. This can create tension between those who feel that the land should be managed for the benefit of the collective, with perhaps a corresponding limited involvement of those who are beneficially entitled to the land in custom from having a voice, and those who want to claim the full rights of owners.

This tension has arisen from time to time in Vanuatu. For example, in the case of Noel $v$ Toto ${ }^{16}$, land held under customary land tenure was producing income in the form of fees collected from tourists visiting a beach on the land. Following family disputes as to who was entitled to benefit from this money the Supreme Court ruled that any income should be divided equally among the family members regardless of sex. Despite this ruling there continued to be intra-family tension, culminating in a further case in 2006. ${ }^{17}$ At the heart of the dispute was the conflict between the

13 This was a concern being expressed in Samoa at the time of the 2008 Symposium due to proposals - which have been mooted for some years - to reform the system of land registration which applies to alienated land.

14 These are known as "vakavanua arrangements."

15 See S Sharma "The control and protection of native lands in Fiji" Working paper No 6 (1999) 3 JSPL http://www.vanuatu.usp.ac.fj/journal_splaw/Working_Papers/Sharma1.html (accessed 21 May 2009) and J Overton "Land Tenure and Cash Cropping in Fiji" in R Crocombe and M Meleisea (eds) Land Issues in the Pacific (University of South Pacific, Christchurch, 1994) 117, 119 and 121.

16 Noel v Toto [1995] VUSC 3 (SC).

17 Noel v Champagne Beach Working Committee [2006] VUCA 18. 
claims of the eldest son to the right of sole ownership and control of the beach and his duty as the representative of the custom owners, including all male and female descendants of the original claimants. On the one hand the family members owed a duty of respect to the head of the family, but on the other failure to co-operate in the management of the land could result in tourists going elsewhere, so he too needed to make decisions which were in the interests of everyone.

Fundamental rights to land also represent a clear example of the relevance of third generation rights in the region. This category of rights has emerged in recent years as a result of the broadening membership of the United Nations and the growing articulation of the concerns of less developed nations. Among these concerns has been the gradual acknowledgment that the influence of economic inequalities in a world which advocates economic rights could itself lead to human rights violations. If there is to be equality of social and economic rights then underlying rights have to be recognised. These include rights to development, peace, a healthy environment and selfdetermination. They may also include the right to humanitarian aid in times of crisis and to benefit from global efforts on the environment.

Although the concept of "third generation rights" is not without its critics, ${ }^{18}$ and the categorisation of rights in this way may be artificial because of the overlap of many rights, it appears that this category of rights envisages not only a domestic rights framework but one that operates in the inter-state sphere, giving effect to the "fraternity" of people and nations. ${ }^{19}$ The rights that might be included under the category of third generation rights are: the right to political, economic and cultural self-determination; the right to economic and social development; the right to participate in and benefit from the common heritage of mankind; the right to peace; the right to a healthy and balanced environment; and the right to humanitarian disaster relief. ${ }^{20}$ Internationally the right to development has been recognised by the General Assembly of the United Nations. ${ }^{21}$ In the

18 For example, J Donnelly "Third Generation Rights" in C Brölmann, R Lefeber and M Zieck (eds) Peoples and Minorities in International Law (Martinus Nijhoff, Dordrecht, 1993) 119; M Freeman "Fifty years of Development of the Concept and Contents of Human Rights" in P Baehr, C Flinterman and M Senders (eds) Innovation and Inspirations: Fifty Years of the Universal Declaration of Human Rights (Royal Netherlands Academy of Arts and Sciences, Amsterdam, 1999) 27.

19 K Vasek cited by Donnelly, above n 16, 122. Vasek's concept of "fraternity" drawn from the three principles of the Declaration of the Rights of Man, envisaged these rights as collective and realisable only by the combined efforts of people, states, public and private associations, and the international community.

20 B Weston "Human Rights" (1984) 6 HRQ 257, 266.

21 Declaration on the Right to Development Adopted by General Assembly Resolution 41/128 of 4 December 1986. Article 1 states: " 1 . The right to development is an inalienable human right by virtue of which every human person and all peoples are entitled to participate in, contribute to, and enjoy economic, social, cultural and political development, in which all human rights and fundamental freedoms can be fully realized. 2. The human right to development also implies the full realization of the right of peoples to selfdetermination, which includes, subject to the relevant provisions of both International Covenants on Human Rights, the exercise of their inalienable right to full sovereignty over all their natural wealth and resources. " 
context of the Pacific it can be argued that if under-developed nations have a right to development, then other members of the international community have a duty to respect this bearing in mind especially the sovereign rights of these nations which entitle them to: first, determine the pace and form of their own development; second, to do so in a way which is conducive to a healthy environment; and third, in a way which is conducive to peace. ${ }^{22}$ It follows therefore that not only do national Governments have an obligation to their citizens not to pursue policies or endorse, either expressly or implicitly - usually by non-action - legal frameworks which put third generation rights at risk, but also that other non-national agencies, such as the World Trade Organisation, the World Bank, aid donors and international forums have an obligation to offer humanitarian assistance in times of crisis. It may also be argued that these non-state agencies have an obligation to ensure that their role in fostering development does not transgress or jeopardise human rights, including third generation rights. ${ }^{23}$

\section{VANUATU}

In Vanuatu as in other Pacific island countries land is everything. "It is a place where niVanuatu can find food and his other basic needs. Land is linked with culture and family relationships. Many people talk about land as "our mother."24

Bonnemaison writing in 1984 stated: $^{25}$

In Vanuatu custom land is not only the site of production but it is the mainstay of a vision of the world.

It represents life, materially and spiritually. A man is tied to his territory by affinity and consanguinity.

The clan is its land, just as the clan is its ancestors. The clan's land, its ancestors and its men are a single indissoluble reality - a fact which must be borne in mind when it is said that Melanesian land is not alienable.

Reclaiming the land was one of the cornerstones of the movement towards independence and a key to national identity. It has in recent years also been the cause of political and racial instability, notably in Fiji and Solomon Islands. At the same time land and its resources are seen as being

22 A Kiss and D Shelton International Environmental Law (Transnational Publishers, New York, 2004) 12, include the right to intergenerational equity, which is a matter of considerable importance in respect of land and natural resources.

23 Although outside the ambit of this paper this has been a matter of concern with oil conglomerates operating in Africa - see for example, C Nwobike "The African Commission on Human and Peoples Rights and the Demystification of Second and Third Generation Rights under the African Charter: Social and Economic Rights Action Center (SERAC) and the Center for Economic and Social Rights (CESR) v Nigeria" (2005) 1(2) AJLS 129.

24 R Nari, Director-General of the Ministry of Lands, address to the National Land Summit (25-29 September 2006).

25 J Bonnemasion "Social and Cultural Aspects of Land Tenure" in P Larmour (ed) Land Tenure in Vanuatu (Institute of Pacific Studies of the University of the South Pacific, Suva, 1984) 1. 
commodities which Pacific islands can, and should, exploit in order to earn hard cash. This is evident in an Australian report entitled "Pacific 2020: Challenges and Opportunities for Growth", published in May 2006. This opens by stating: ${ }^{26}$

The overall performance of the Pacific island countries in the course of the past two decades has been poor. The region suffers from high unemployment and joblessness, and governments are failing to meet the expectations of their citizens. Several countries suffer from social or political instability, or serious crime. Some face daunting health or environmental challenges. Without an upturn in economic growth, the future for these countries is at best uncertain and at worst bleak.

It goes on to indicate that four out of five Micronesian countries had negative economic growth and that in Melanesia only Fiji managed an economic growth rate over one per cent in the period 1990-2004 - although since 2006 Fiji's economy has declined while that of Solomon Islands has improved. Throughout the region economic growth was lower than comparable developing countries. The report suggests that there are three economic possibilities facing the region: failure to achieve economic growth; maintenance of the status quo buoyed up by aid packages and outward migration; and rapid economic growth facilitated by major reforms. The report advocates the latter. It identifies as the major obstacles to positive economic growth: weak governance and poor functioning of Government institutions; poor and insufficient infrastructure; insufficiently developed regional co-operation and economic integration and lack of commitment to implement reforms. The report focuses on five areas of productivity which it sees as needing development if economic growth is to be achieved. These are: agriculture, fisheries, forestry, mining and petroleum, and tourism.

These are areas of activity already being exploited and developed in the region often with little thought being given to sustainability, the social and environmental impact on indigenous people, or the long-term impact on the survival of Pacific islands subject to such exploitation. The exploitation of what are primarily natural resources, while it might be good for the economy - at least in the short term, can pose considerable difficulties and challenges for a range of fundamental rights. At the same time it is clear that near neighbours are encouraging Pacific islands towards more rapid development and greater exploitation of resources.

In 2008 AusAID published a document entitled "Making Land Work" as part of its "Pacific land programme". ${ }^{27}$ While not seeking to be prescriptive in its advice, the document suggests that reform to land tenure can both deliver security to custom land owners and to investors. At the same time, however, it suggests inter alia that land policies must reflect local needs and circumstances, that long timeframes must be accepted, that stakeholders must be actively involved and that vulnerable groups must be safeguarded. The Vanuatu example suggests that these various principles may be

26 http://www.ausaid.gov.au/publications/pdf/pacific2020.pdf (accessed February 2008).

27 AusAID "Making Land Work" www.ausaid.gov.au/publications (accessed 21 May 2009). 
incompatible. Development is rapid. Lack of centralised land policy, planning, zoning and use control mean that development is uneven, resulting in the displacement of some groups of customary land users while excluding others from any benefits of development. Stakeholders are not always involved in decisions, especially women, and where land is managed by trust boards, agents or even government ministers, the views of stakeholders may be irrelevant. The language of land law, especially relating to leases, continues to be an obstacle to understanding what rights and interests are at stake, and any land policy reform that is put in place may be too little too late.

A further problem, however, is that invariably land reform is framed in Western concepts such as registration of title and indefeasability of that title; cadastral survey; and the determination of disputes by forums which may not consider fundamental rights, which may not be truly representative - especially as both formal and customary forums tend to be dominated by men, or which may be unconcerned with providing safeguards for vulnerable groups. In particular one aspect which is not sufficiently addressed by "economic advisers" or "development consultants" is the basic difference in perceptions of land. For non-Pacific islanders from developed countries, land is a commodity, which can be traded like any other. For Pacific islanders, however, land is the indigenous heritage of people.

Neither of the Australian reports pause to consider whether brakes should be placed on land development or restrictions imposed either to prevent further foreign investment in land, ${ }^{28}$ or to regulate the forms of investment which are most desirable - for example sustainable logging of renewable resources or diversity of agricultural productivity in partnership with customary land holding groups.

While the 2008 document suggests that the way ahead is to reconcile customary land tenure and development by "linking customary land into formal economic and legal systems, broad community consensus, extensive technical and managerial skills and long timeframes and adequate funding", ${ }^{29}$ it perhaps underestimates conceptual, institutional and practical difficulties. ${ }^{30}$

The exploitation of land and natural resources in the region raises questions about: the right to development and the right to a sustainable environment - and whether these two are compatible; the internal and external forces that determine the pace of change and the issue of self-determination in

28 For example, the purchase of land for residential development by non-citizens could be prohibited - as in some of the Channel Islands.

29 "Making Land Work", above n 26, 133.

30 See for example K Brown "The Language of Land: Look before you Leap" (2000) 4 JSPL http://www.paclii.org/journals/fJSPL/vol04/ (accessed 1 June 2008); S Farran "South Pacific Land Law: Some Regional Challenges, Cases and Developments" (2001) 32 VUWLR 953; J Mugambwe "Judicial Assault on the Citadel of Indefeasibility of Title under the Papua New Guinean Torrens System of Conveyance" (2001) 5 JSPL http://www.paclii.org/journals/fJSPL/vol05/ (accessed 1 June 2008). 
deciding priorities and policies; the duty owed by the national government to its citizens; and the obligations of the international community towards Pacific Island countries.

\section{CONSTITUTIONAL PROTECTIONS}

The protection of property rights is recognised as a fundamental right. ${ }^{31}$ Indeed this is acknowledged in most of the regional constitutions as a right separate from the right to privacy or security from unwarranted search and seizure. What is meant or understood by "property" in this context may include rights to land and other property or this may be unspecified. For example, in Tonga there is no separate right to property but under section 1, Part 1 of the "Declaration of Rights" it is stated under the "Declaration of Freedom" "all men may use their lives and persons and time to acquire and possess property and to dispose of their labour and the fruit of their hands and to use their own property as they will." In some cases this right to property is included among those with respect to which discrimination is prohibited, ${ }^{32}$ although in fact discrimination in respect of certain property rights, especially land, is a feature of the region. ${ }^{33}$ Elsewhere the right is stated to be a right not to be deprived of property, or a right to due process, or a right to compensation. ${ }^{34}$ These rights are closely interrelated.

A person may lawfully be deprived of their property in certain circumstances which can be broadly divided into two categories: first where loss or confiscation of property is a consequence of personal circumstance and occurrences such as bankruptcy, mortgage default, criminal activity, tax liability or an order of court; ${ }^{35}$ and second where the Government appropriates such property for purposes beneficial to the public. ${ }^{36}$ In this latter case there are a number of elements to be satisfied if the deprivation is to be lawful. These include deprivation in accordance with the law; for a public

31 See, for example, ss 8 and 9 Kiribati; Article IV ss 3 and 5 Federated States of Micronesia, ss 40(1) and 64 (1)(c) Cook Islands; sections 8 and 9 Nauru; section 14 Samoa and Art 5(1)(j) Vanuatu. In Tonga property may only be taken in time of war, or to make Government roads or for other works beneficial to the Government (s 18). Note that in the Fiji Bill of Rights there is no express right to protection of property which, given the ethnic discrimination in land rights in Fiji is perhaps not surprising.

32 See, for example, Kiribati, Nauru and Solomon Islands, Tuvalu, and Vanuatu.

33 For example, foreigners may not own customary land in any country of the region. In some countries noncustomary land may be owned by foreigners, for example, Cook Islands, Fiji and Samoa - although in Samoa the Head of State must approve this - Alienation of Freehold Land Act 1972, s 6, but in others this is also prohibited. Discrimination on the grounds of gender also occurs; see S Farran, "Land rights and gender equality in the Pacific region" (2005) 11 APLJ 131.

34 See, for example, Marshall Islands Constitution, s 5.

35 For example in the case of insanity, divorce, acquisition by prescription or to effect a trust of property by vesting title in the trustees.

36 Sometimes these may overlap, for example, where a person is deprived of their property because it is dangerous. 
purpose ${ }^{37}$ and in return for the timely payment of an agreed or just compensation determined by taking into account the criteria specified either in the Constitution or in supplementary legislation. Such compensation may include relocation or the provision of alternative land/housing as well as financial or other non-financial compensation. ${ }^{38}$ Those deprived of their property should also have the right to due process and access to the courts to challenge any such deprivation. These types of provisions are very much modelled on Western-liberal conceptions of private property.

However, if Governments have a duty not only to observe the letter of the Constitution but also its spirit then it is suggested that the right to property goes further than questions of due process and just compensation in the context of state acquisition. The protection of property rights should be seen as imposing a positive obligation on states and the wider community to adopt policies and take measures which safeguard the property of Pacific island people, including - but not solely - land.

\section{$V$ THE VANUATU EXPERIENCE}

The population of Vanuatu is not huge by international standards. In 2007 it was estimated to be around 212,000 , with an estimated annual growth rate of $1.46 \%$. Thirty-two per cent of the population is under the age of $14 .{ }^{39}$ Employment opportunities are limited and outward migration almost zero. There is increasing urban drift. Many young people are now second or third generation dwellers. They have no inclination to return to the original island homes of their parents and may have no claim to land in the islands, especially if their parents are unmarried or have been married but are now separated. Urban poverty and urban crime is on the increase, including property crime. It has been suggested that the urban population will double in size in the next twenty years. ${ }^{40}$

The country's economy is based primarily on small-scale agriculture, which provides a living for 65 per cent of the population, ${ }^{41}$ fishing, financial services (offshore) and tourism. ${ }^{42}$ Unlike its near neighbour Solomon Islands, Vanuatu has virtually no timber worth felling as its sandalwood forests were cut down by traders long before independence, nor does it have large mineral deposits as is the

37 For example, public defence, safety, order, morality, health or planning and development.

38 See, for example, Constitution of the Republic of Palau Art IV, s 6; Constitution of the Marshall Islands, s 5(6); the Constitution of Solomon Islands 1978, s 8(1)(c)(i)

39 CIA World Factbook: Vanuatu https:/www.cia.gov/library/publications/the-world-factbook/geos/ nh.html\#People (accessed 10 March 2008).

40 M Henare "Putting People First" (European Society of Oceanists Conference, Verona, 10 July 2008).

41 Some sources claim this percentage to be as high as 80. See opening speech at the National Land Summit by the Minister of Lands in Government of Vanuatu "National Land Summit Final Report" (2007).

42 For an overview see https:/www.cia.gov/library/publications/the-world-factbook/geos/nh.html\#Econ (accessed 1 June 2008). 
case in New Caledonia, Papua New Guinea or even Solomon Islands. ${ }^{43}$ Compared to Fiji Islands it has limited manufacturing or retail activity and its off-shore financial services and status as a taxhaven are constantly under scrutiny. The challenges for Vanuatu are how to balance opportunities for development with the needs of a rapidly growing population for whom there are limited employment opportunities, a limited land mass - most of which is vested in customary owners, and limited alternative resources. As elsewhere in the region there is pressure, both internally and externally, for Vanuatu to attract inward foreign investment. One of its main means of doing this is to exploit the land, either by way of tourism development, or by accommodating individuals seeking second or holiday homes.

The consequence of this has been rapid land alienation in the last ten years, especially on the capital's island of Efate, coastal land and small outer islands. Indeed it would appear from survey maps accessed in 2007 that almost all the peripheral land of Efate has now come under leasehold and other islands are also becoming the target of property developers. Not only does this mean that all the coastal land is being potentially taken out of use for customary owners and the general public - for leisure purposes for example, but these coastal leases tend to run inland over potential agricultural land, ${ }^{44}$ and also into areas of natural bush designated suitable for a national park in the north-west of Efate.

The situation in Vanuatu is due to a number of factors. First, because so much land had been alientated to foreigners in the century before independence when the 1980 Constitution returned land to customary ownership, it was necessary to put various transitional provisions in place. Among these was a power reserved to the appropriate Minister to manage land where the identity of custom owners could not be established or where there was a dispute as to who the rightful owners were. ${ }^{45}$ This power continues so that even today the Minister of Lands yields considerable and often unaccountable power over land which is not public or state land. In particular he has the power to grant leases over land. The fact that the Minister can give good title to a lease means that anyone seeking to lease land - especially an increasing number of land-developers or estate agents, who are invariably ex-patriates, far prefer to acquire land held under the Minister's powers than to go to the trouble of dealing with custom owners, who may be difficult to ascertain, undecided and lacking unanimity. Ministers of Lands have therefore been key players in granting a high percentage of the many leases which currently exist. ${ }^{46}$

43 Although there have been proposals to re-open the iron ore workings at Forrari on the north- east coast of Efate.

44 A number of former cattle ranches have already succumbed to sub-division. As organic beef is one of the important agricultural exports of the country this may be under threat if this type of land use continues.

45 Constitution of the Republic of Vanuatu, Art 78(1).

46 S Farran "Ministerial leases in Vanuatu" Working Paper (2003) 9 JSPL available online http://www.vanuatu.usp.ac.fj/ (accessed 1 June 2008). 
Second, while foreigners who had acquired freehold titles prior to independence could no longer hold such titles to land - as freehold was abolished entirely, they could enter into leases of land. Thus leases became an integral part of the Vanuatu legal landscape. Initially these were primarily agricultural leases of thirty or forty years' duration. Under the Land Leases Act (Cap 163) however there is scope for leases to be of seventy-five years duration, and as the shift has been away from agricultural leases to residential leases, this period has become common, as has the use of subdivision of larger plots - many of which were formerly agricultural holdings, usually by developers.

Third, the introduction of the foreign concept of "strata titles", has facilitated the process of subdivision further. Although the purported aim of the Strata Titles Act 2000 was to provide for the sub-division of buildings into separate lots by registering a strata title plan and thereby afford security to small businesses in shared urban buildings, it is evident that the Act has been used for the sub-division of undeveloped land outside the urban areas and that this is in fact facilitated by amendments made to the original Act in 2003. As the Land Leases Act already provides for subdivision it is suspected that the Strata Title Act has been used because it lacks the safeguards for lessors - the custom owners - found in the Land Leases Act.

Fourth, and perhaps ironically, political instability elsewhere in the region especially in Fiji Islands and Solomon Islands has seen an upswing in tourism to Vanuatu. Visitors are bombarded with the advertisements of property developers who are keen to sell them land, which can be found in the in-flight magazine of the national airline, on the internet and in the shop-front windows of high street estate agents in the capital Port Vila.

This surge in land alienation, whether by the Minister, by developers or representatives of custom owners has led to much of Efate and a number of the off-shore islands coming under leasehold. In 2002 it was estimated that a quarter of the entire island of Efate was under leasehold, with the majority of leases being on prime coastal land. ${ }^{47}$ In 2008 it was estimated that as much as fifty percent of Efate was under lease. ${ }^{48}$ Significantly, the majority of these prime site leases are not held by indigenous people but by foreigners. In the peri-urban area of Port Vila customary land owners are finding themselves squeezed out and the general public is being denied access to beaches, the reef and former gardening land. Escalating urban migration has led to a number of squatter settlements within and on the outskirts of Port Vila - most of which are not seen by tourists, increased inland bush clearing for food cultivation, increased theft from gardens and problems of law and order. This is turn has led to suggestions by some traditional leaders that freedom of movement should be restricted so that islanders who do not have customary land on Efate are prevented from settling on the land of others, and that young persons who cause trouble should be

47 Ibid. This was a statistical calculation based on close scrutiny of all registered leases outside the Port Vila municipal boundary.

48 J Fingleton, A Naupa and C Ballard "Village land trusts in Vanuatu: 'one common basket' in "Making Land Work" above n 26, Vol 2, 21, 24. 
"sent back to the islands". Research undertaken in 2007 indicated that where properties had been acquired and developed by non-ni-Vanuatu, self-help security measures were increasingly evident, including the use of guard dogs, private security patrols, barriers across roads, electric gates and razor wire above walls and fences. ${ }^{49}$

Vanuatu is not oblivious to the problems of rapid land alienation and the threat to the property interests of indigenous people. During the course of 2006 a number of provincial meetings and consultations took place to consider land issues. ${ }^{50}$ These culminated in a National Land Summit in September 2006. The aim was to review issues of land management and development. In particular a need to address issues of land ownership, fair dealing, and the role of Government in the management and development of land were identified as key issues. What was interesting about the Summit was not only that it generated considerable public debate and participation, but also that although it was facilitated by donor funding, the outcomes at first instance were those of the indigenous people.

These were articulated in a list of twenty resolutions many of which sought to strengthen customary property rights. In summary these were: the law should recognise and give effect to communal ownership of land; the central and provincial governments and the National Council of Chiefs should work together to document the custom (kastom) that determine ownership, land policies, boundaries and land dealings; greater awareness of the existing (plural) legal and economic framework should be undertaken; the current law of leases should be reviewed; lease agreements should be made comprehensible and inclusive in their negotiation and agreement; certificates of negotiation should be subject to increased scrutiny and publicity, especially at the local level; the Minister should cease to have the power to approve leases over disputed land; abuses of the use of strata title should cease and land owners be involved in their approval; real estate agents should be regulated; lease rental and premium rating should be reviewed and reformed; pre-approval conditions directed at ensuring sustainable development should be put in place and effectively enforced; physical planning and zoning laws should be strengthened and a sub-divisions policy put in place at national and provincial level, and efforts should be made at all levels and to all sectors of the community to raise awareness of sustainability issues.

Following the Summit a local Steering Committee was formed to take matters forward. 2008 was envisaged by the Lands Steering Committee as the year in which there woould be increasing public awareness of the land issues highlighted at the 2006 summit, leading to a new Land Law Act in 2009. Whether this latter target will be met remains to be seen. However, some steps have been taken. For example, immediately following the Summit a moratorium was imposed on the granting

49 S Farran "Selling the Land: Should it Stop?" (Society of Legal Scholars Conference, Cambridge, April 2008).

50 National Land Summit, Final Report, above n 40, 15. 
of new sub-divisions and the surrendering of agricultural leases; ${ }^{51}$ detailed draft laws have been formulated to govern land use; guidelines for land sub-division have been drafted; fieldwork has been started to establish customary boundaries and case-studies have been undertaken to establish a factual understanding of customary tenure at ground level. Proposals that the power of the Minister of Lands be curtailed have not been successful, probably because this would have entailed the Minister himself introducing the motion. It might also be noted that many of those who are in power have vested interests in land development, for example because they come from those areas benefiting most from this, especially Ifira, ${ }^{52}$ and may be politically reluctant to "kill the goose that lays the golden eggs".

A second consequence of the Summit was that aid funding was found to support a consultancy "review" team to come up with proposals. In 2007 the Review team produced a report which suggests that key issues which needed to be addressed were: lack of a national land policy, ${ }^{53}$ weaknesses in land administration and a need to reform the law. It has proposed aid-funded programmes to build capacity and good governance in the public sector and to strengthen the various institutions which facilitate land transactions. While these proposals may improve the administration of land dealings it is questionable whether they will address a more fundamental question which is whether the continued alienation of land to predominantly foreigners, is compatible not only with the sustainable development, peace and security of the people of Vanuatu but with the fundamental right to live on their own land. These measures will also not address the question, left unanswered by the provision in the Constitution that all matters pertaining to land should be determined by reference to custom, namely what is that custom and is it compatible with human rights?

At the time of writing an interim coalition Government is in power pending national elections, for which a large number of candidates are putting themselves forward, many as independents. Government changes may mean that some of the impetus of the National Land summit and its resolution will be lost. ${ }^{54}$ In the meantime there is real concern among local people, especially those who are not benefiting from the economic profits of land alienation, or who have made short-term gains but see longer-term misery ahead.

51 It now appears that the moratorium was never implemented (April 2009).

52 See Fingleton, Naupa and Ballard, above n 47, 24.

53 Guidelines for which were subsequently published in the 2008 "Making Land Work" Report by AusAID referred to above $\mathrm{n} 26$.

54 At the time of going to press the elections have been held. A new Government is in place, but not one of the land resolutions have been given effect although the Vanuatu Government has produced a draft "Land Sector Framework" 2009-2018" document - with the help of AusAID. 
As with so many areas of development there is a tension. Although a number of the resolutions of the land summit indicate that the appropriate response lies in improved central administration, in many ways this is at odds with resolutions advocating more involvement by customary land owning groups, a greater role for chiefs, and non-governmental agencies, such as the Vanuatu Cultural Centre. Enhancing the role of customary custodians of land could be a double sided sword. A recent example emerges regarding claims for compensation in repect of damage to property caused by the construction of a round-island road under a Millenium Development project funded by the United States of America. The executive of Efate island council of chiefs, the Vaturisu, decided on 22 July 2008 , that any claim was to be directed to a nominated spokesperson on the council. ${ }^{55}$ Should there be any disputes then these were first to be referred to the village level and as a final resort to the Vaturisu. While this will leave the construction company free to get on with its work and the project managers need not concern themselves with issues of compensation, it does mean that individuals who have a constitutional right to the protection of property and against unjust deprivation of it, ${ }^{56}$ are effectively being denied access to the Supreme Court, which is the court of jurisdiction for alleged breaches of fundamental rights. ${ }^{57}$

There is also a fundamental dilemma between the rights of individuals to manage and, if they so want lease their land, for seventy-five years and use the money as they wish - exercising their social and economic rights, and the need to preserve land for future generations. Money realised by the premium and rents attaching to a lease are not the sole beneficial property of the present customary owners - as illustrated by the case of Noel $v$ Toto mentioned above. Therefore any monies should be placed in trusts and managed accordingly. Frequently this does not happen. Where is does, the management of funds may lack transparency, beneficial distribution may be inequitable and sound financial management may be questionable. This is not solely attributable to lack of probity although that too may be a problem, but to lack of understanding regarding the institution of the trust - which is after all an introduced concept, and lack of appreciation of the duties and obligations of the trustee role. As a consequence, it can happen that funds realised by the granting of leases are rapidly consumed or dissipated.

In countries such as Vanuatu, with restricted usable land because of the steep volcanic interiors of islands and poor access, land is not limitless. As elsewhere in the Pacific region many of the population remain dependent on the land for subsistence, and may have nowhere else to go. The challenge is therefore how to ensure "that traditional land tenure systems remain viable and relevant in a global economic system propelled by market forces". ${ }^{58}$ This is a question which should engage

55 (24 July 2008) Vanuatu Daily Post Port Vila 4.

56 Constitution of the Republic of Vanuatu, Art 5(1)(j).

57 Ibid, Art 6(1).

$58 \mathrm{H}$ Amankwah "Traditional values and modern challenges in property law" (2007) 11 JSPL http://www.paclii.org/journals/fJSPL/vol11no1/ (accessed 1 June 2008). 
not just national Pacific Governments but also the international community. It is a matter of fundamental rights. If there is to be development then more effort will have to be made to ensure that it is sustainable, not just for the "get-rich quick" present generation but for future ones. In 2006 the National Land Summit held a National Youth Essay and Poster Competition. A twelve year old prize-winner wrote this: ${ }^{59}$

By the year 2015, people might have sold out most of their lands which is not good. If they continuously sell their lands, where will their fourth or fifth generations live? Maybe they will be sitting along the streets begging for food and without any jobs. So I think that that's not a good stage for people to be at,

or else Vanuatu will get worse than other Pacific islands.

\section{CONCLUSION}

The relationship between economic development and human rights is a difficult one. Internal and external pressure to attract inward investment, improve opportunities for participation in a monetary economy and achieve capital growth may mean that individual needs are sacrificed or shelved to meet national growth plan targets, which in turn are geared to satisfying regional goals or international standards, for example, to enter into an EU-ACP agreement or to comply with WTO membership criteria. Incentives for economic development and participation in its benefits can lead to widespread and sometimes gross inequalities of wealth with the gulf between the rich and poor leading to social unrest and civil disturbance. This may be aggravated along ethnic lines where wealth or resources are perceived as being enjoyed by one particular group at the expense of another. This economic aparthied may be particularly noticeable in countries which are shifting from subsistence agricultural to monetary economies and are experiencing considerable urban migration and where the disparity in disposable wealth between those who can participate in and benefit from a monetary economy and those who cannot, may be especially great.

Of course it may be argued that these negative trade-offs for economic growth are merely temporary and that ultimately equality, freedoms and needs will all be met and that civil and political rights will thrive. The truth is, however, that often economic development is taking place so rapidly that the victims of it are left behind and long-term consequences are conveniently ignored in favour of short-term gain. Moreover inequalities of wealth combined with inequalities of political power can result in a self-perpetuating system of human rights denial, especially where those who most benefit seek to preserve the unequal status quo. It is rare therefore to find development matched with an enhancement of civil and political rights as well as economic and social rights.

Unless land issues are addressed and seen as being integral to concerns about human rights, then all other rights may be at risk.

59 L Laliet "Youth and Land in 2015" in A Naupa Youth and Land in 2015: Selections for Vanuatu's 2006 National Land Summit Youth Essay and Poster Competition (Australian Government/AusAid, Port Vila, 2006). 